IZA DP No. 9340

Remittances and Credit Markets:

Evidence from Senegal

Linguère Mously Mbaye

September 2015

Forschungsinstitut zur Zukunft der Arbeit Institute for the Study of Labor 


\title{
Remittances and Credit Markets: Evidence from Senegal
}

\author{
Linguère Mously Mbaye
}

IZA

\section{Discussion Paper No. 9340 \\ September 2015}

\author{
IZA \\ P.O. Box 7240 \\ 53072 Bonn \\ Germany \\ Phone: +49-228-3894-0 \\ Fax: +49-228-3894-180 \\ E-mail: iza@iza.org
}

\begin{abstract}
Any opinions expressed here are those of the author(s) and not those of IZA. Research published in this series may include views on policy, but the institute itself takes no institutional policy positions. The IZA research network is committed to the IZA Guiding Principles of Research Integrity.

The Institute for the Study of Labor (IZA) in Bonn is a local and virtual international research center and a place of communication between science, politics and business. IZA is an independent nonprofit organization supported by Deutsche Post Foundation. The center is associated with the University of Bonn and offers a stimulating research environment through its international network, workshops and conferences, data service, project support, research visits and doctoral program. IZA engages in (i) original and internationally competitive research in all fields of labor economics, (ii) development of policy concepts, and (iii) dissemination of research results and concepts to the interested public.
\end{abstract}

IZA Discussion Papers often represent preliminary work and are circulated to encourage discussion. Citation of such a paper should account for its provisional character. A revised version may be available directly from the author. 
IZA Discussion Paper No. 9340

September 2015

\section{ABSTRACT \\ Remittances and Credit Markets: Evidence from Senegal*}

This study investigates the impact of remittances on credit markets in Senegal. The findings show that remittances and credit markets are complements; namely, the receipt of remittances increases the likelihood of having a loan in a household. This result is robust after controlling for the potential endogeneity of remittances through household fixed effects and an instrumental variable approach. A detailed analysis also shows that the impact of remittances on credit markets is mainly driven by loans taken for consumption and food, in particular, as well as loans provided by informal institutions.

JEL Classification: F24, O15, O16

Keywords: migration, remittances, credit markets

Corresponding author:

Linguère Mously Mbaye

IZA

P.O. Box 7240

53072 Bonn

Germany

E-mail: mbaye@iza.org

\footnotetext{
* I am grateful to Alpaslan Akay, Costanza Biavaschi, Benjamin Elsner, Kwabena Gyimah-Brempong, Xingfei Liu, Massimiliano Tani and Natascha Wagner for valuable comments on previous versions of this paper. This paper benefits from discussions with Deborah Cobb-Clark, Marcel Fafchamps and Mark Rosenzweig. I thank seminar and conference participants at the ASSA Annual Meeting, 2012, Chicago, USA; IZA seminar, Bonn, Germany; $12^{\text {th }} \mathrm{AM}^{2}$, Dakar, Senegal. The usual disclaimer applies.
} 


\section{Introduction}

Migration and remittances play a crucial role in developing countries; for instance, there are around 30 million migrants who account for $3 \%$ of the population in Africa. Remittances represent two-thirds of the size of aid flows and in most low-income countries of sub-Saharan Africa they exceed private capital flows such as foreign direct investment (FDI) (Ratha et al., 2011). Credit markets are also important for developing countries, although the proportion of formal loans remains low due to many factors, including the lack of collateral provided by borrowers.

Nonetheless, the relationship between remittances and credit markets remains largely unexplored. Our study is a new contribution to the literature related to the impact of migrants' transfers in their origin countries in the context of rural credit markets. Moreover, by examining how remittances are important for credit markets, we believe that we solve an important empirical question related to the substitutability and complementarity between these two variables.

In this paper, we assume that migrants can positively influence the credit markets through their remittances, by being the collateral, the "third element" or the "element of trust" in the credit contract between the borrower and the lender, representing a potential alternative in case of non-repayment. At the same time, remittances and credit markets can be substitutes due to the imperfections of credit markets. In this case, one would expect a negative relationship between remittances and credit markets.

We adopt a microeconomic perspective by focusing on rural areas where the financial constraints are more challenging. The survey data are from Senegal ${ }^{1}$ and provide information about the remittance status of the household. More precisely, the interest variable is a dummy equal to one if the household receives remittances and zero otherwise. We also have information about the presence or absence of loans, as well as the characteristics of

\footnotetext{
${ }^{1}$ International migrants' transfers are estimated at 40 billion $\$$ which represents $2.6 \%$ of Africa GDP in 2010. In Senegal, remittances are one of the main income resources of the country and are estimated at $9.3 \%$ of GDP making Senegal one of the large remittances recipients in sub-Saharan Africa (Ratha et al., 2011).
} 
these loans, whenever they exist. We make use of this detailed information to explore the different channels through which remittances can influence credit markets, i.e. we study the reasons for a loan and whether it is provided by formal or informal institutions. In the empirical analysis, we start by employing a linear probability model. The results show a significant and positive effect of the receipt of remittances on the probability of having loan in a household. These results are robust to the inclusion of household head and general household characteristics, as well as income and the occurrence of shocks.

However, the main concern for identification is the possible endogeneity of the receipt of remittances. Remittances are potentially endogeneous, first, due to the non-random selection into migration. If remittance recipients and non-recipients are different in terms of unobservable, this could bias the estimated effects. Second, the non-inclusion of some omitted variables can bias the relationship between remittances and credit markets. A third issue is that loans can fund migration and remittances can be sent to repay loans. If this is the case, there is a reverse causality between remittances and loans. To assess the robustness of the findings, it is thus crucial to identify the source of variation of remittances. Subsequently, we address the endogeneity of remittances by using a fixed effects model and instrumental variable approach. A household fixed effects model controls for the selection and omitted variable biases and shows that the receipt of remittances increases the likelihood of having a loan by 11.8 percentage points. In addition to the fixed effects model, we use an instrumental variable approach to deal with the reverse causality bias. The identification strategy benefits from the long migration history of Senegal and the role of the harbor of Dakar in setting up historical migration networks. The harbor was built in 1866, during the time of French colonialism. It contributed to the development of the city of Dakar, which attracted many internal migrants. Due to its strategic location, the harbor of Dakar was also the place from which Senegalese migrants first left for France. As a source of variation, we use the distance from a village to the harbor of Dakar. This distance is an exogeneous measure of the cost of migration between 1900 and 1960, when the first Senegalese mi- 
grant networks were formed. A key issue is that the instrumental variable should meet the exclusion restriction. Since loans are drivers for investment, a lack of access to credit markets could negatively affect a village's level of development, which in turn will increase remittances through an increase in migration flows. We rule out this source of bias by controlling for the village level of development. After correcting for the endogeneity of remittances, the results remain significant and positive. Overall, the findings of this paper support a complementarity between remittances and credit markets. A detailed analysis shows that the positive effect of remittances on credit markets is mainly driven by loans taken for consumption and food, in particular, as well as loans provided by informal institutions.

The remainder of the paper is organized as follows. Section 2 presents the existing literature and the theoretical framework for understanding the relationship between remittances and credit markets. Section 3 describes the data, before Section 4 discusses the identification strategy, results and heterogeneous effects. Finally, the last section concludes.

\section{Background on remittances and credit mar- kets}

\section{$2.1 \quad$ Literature}

The relationship between remittances and credit markets is ambiguous à priori. On the one hand, remittances can provide insurance to households and increase their willingness to participate in credit markets. For instance, Aggarwal et al. (2011) find that workers' transfers contribute to the development of the financial sector and have a positive impact on economic development. Demirgüç-Kunt et al. (2011) find further evidence for this effect by showing for the case of Mexico that remittances increase the number of bank branches, accounts and deposits in the recipient country. This pos-

itively affects the depth and breadth of the banking sector. These authors demonstrate a positive impact of remittances on the share of credit volume 
to GDP. For sub-Saharan Africa, Gupta et al. (2009) finds that remittances improve the financial development in the origin countries of migrants by facilitating poor households' access to formal financial markets. On the other hand, remittances can help in dealing with credit market imperfections and reduce the credit demand by relaxing financial constraints (Mesnard, 2004), increasing investments and developing small enterprises (Woodruff and Zenteno, 2007) or helping households facing health shocks (Ambrosius and Cuecuecha, 2013). Furthermore, Brown et al. (2011) find a negative relationship between remittances and the financial deepening in developing countries. More specifically, Richter (2008) studied the effect of remittances on rural credit markets, analyzing the effect of the potential receipt of remittances on the credit demand of rural households in the Mexican state of Oaxaca. Her results suggest that the predicted amount of remittances received at the household level has a positive effect on credit demand.

\subsection{How can remittances affect credit markets?}

In the following, we will explain channels of transmission through which migrants and remittances affect credit markets. Migrants can make it easier for the remaining households to gain access to credit markets, thereby increasing the likelihood of those staying behind securing a loan. However, by sending remittances, migrants can also reduce the need of the remaining household members to ask for a loan.

Channel 1: Remittances and credit markets are complements

The presence of a migrant in a household can increase the likelihood of securing a loan. As shown in the previous literature, migrants play an insurance role against shocks through their remittances. According to Udry (1994) in the context of rural areas, borrowers who deal with negative shocks are more likely to default. Moreover, repayments can depend on random production and consumption shocks, which affect both borrowers and lenders. We consider that migrants - who by definition are not present in the community - serve as collateral in case of non-repayment due to shocks. Therefore, the credit contract includes the borrower, the lender and the migrant. In 
this case, the role of trust of migrants is explained by the level of information asymmetry between the borrower and the lender. Indeed, if we consider that information asymmetries are low in rural areas and most are informal (Udry, 1994, 1990), lenders know whether a borrower has a migrant in the household. Moreover, it is very likely that lenders know the characteristics of these migrants, such as their gender, age or the country to which they have migrated. Therefore, migrants can be a collateral and play a "psychological" role concerning the lenders' level of trust. We assume that migrants serve as a signal of reliability of their borrowing family members because they constitute a potential alternative in case of non-repayment. Another aspect in favor of the "migrant as collateral" is that risk sharing within the same community is not feasible when households face covariate shocks. According to Conning and Udry (2007), this increases the willingness to make arrangements outside the community. Therefore, rural credit markets are fragmented and imperfect and lenders who do not necessarily belong to the borrower's close network have to deal with high information asymmetries. Indeed, they cannot check the reliability of the borrowers, which increases the costs of the loans. This is where migrants come into the picture: through their remittances, they can make borrowers more reliable, thus enabling their easier access to credit. Migrants act as insurance for lenders and increase the likelihood of household members staying behind securing loans.

Channel 2: Remittances and credit markets are substitutes

On the other hand, credit suppliers and migrants can both play an insurance role and can be considered as substitutes. If this is the case, we would expect a negative relationship between remittances and credit markets. Nonetheless, covariate shocks make access to credit markets difficult by increasing the interest rate or weakening solidarity mechanisms in the community where all households are affected by the same shocks (Yang and Choi, 2007). Fafchamps and Lund (2003) show that gifts and informal loans are highly correlated with negative shocks, while small networks and relatives represent the primary source of help for rural households that have to deal with shocks. For instance, Rosenzweig (1988) compares the role of credit and inter-household income transfers in smoothing consumption ex post, show- 
ing that inter-household transfers can substitute for credit arrangements and that family transfers are preferred to credit arrangements - over space and over time - above all if credit supply is limited due to an under-performing local economy.

The purpose of the empirical part is subsequently to test these assumptions and explore the nature of the relationship between remittances and credit markets.

\section{Data}

\subsection{The survey}

The data stem from a survey carried out in two waves in rural areas of seven regions of Senegal. ${ }^{2}$ The first wave took place between May and July 2009 and the second wave between April and June 2011. The survey was part of the program evaluation of a rural electrification initiative by UNDP, known as a multifunctional platform. The sample comprises 165 villages, which were randomly selected based upon the criterion of not having access to the national grid. ${ }^{3}$ Within the villages, households were also selected randomly from the list of residents supplied by the head of the village. The sample is thus representative of rural Senegalese areas in which subsistence agriculture is the most prevalent form of income generation.

For this analysis, households are the unit of observation because migration information is supplied at the household level and most of the loans are used for food. ${ }^{4}$ In the context of Senegal and more specifically in the rural context, people generally share meals and familial expenses. Consequently, it is reasonable to use loan information aggregated at the household level.

\footnotetext{
${ }^{2}$ The regions are Kaolack, Fatick, Diourbel, Tambacounda, Kolda, Thies and Louga.

${ }^{3}$ This is not a drastic restriction since the rural electrification rate was only about $20 \%$ including off-grid solutions in 2008 (Mawhood and Gross, 2014).

${ }^{4}$ See below descriptives for loan reasons.
} 


\subsection{Descriptive statistics}

Table 1 reports the summary statistics by remittance status of the household. We show the results for households with and without remittances, whereby remittance non-recipients are significantly less likely to have loans than recipients. There are no significant differences between households with and without remittances in terms of the marital status of the household head, origins of loans, reasons for loans - such as for consumption and food, the share of children, belonging to the Wolof ethnic group, ownership of a radio and mobile phone and access to drinking water. Nonetheless, household heads of remittance recipients are more likely to be older and literate than those of remittance non-recipients. Remittance recipients are more likely to take loans for investment reasons and more precisely for investment in professional activities. Moreover, remittance recipients have a higher likelihood of being polygamous households relatively to non-recipients, as well as more likely belonging to the Mande ethnic group. By contrast, they have a lower likelihood of being from the Pular ethnic group. Remittance non-recipients have lesser access to electricity and good living conditions (concrete house) and fewer plots than recipients. Non-recipients are more likely to deal with covariate shocks and less likely to face idiosyncratic shocks compared to recipients. Non-recipients of remittances have a higher likelihood of having a cellular network in their village than recipients. Finally, remittances recipients are more likely to live further away from Dakar than non-recipients, as well as being more likely to live in villages where there is at least one school and in which the level of poverty increased during the five years prior to the survey.

\section{The impact of remittances on credit mar- kets}

\subsection{OLS Estimates}

We estimate the following linear probability model: 


$$
y_{i t}=\alpha+X_{i t}^{\prime} \beta+\text { Remit }_{i t}+\epsilon_{i t}
$$

The unity of observation is the household $i$ at year $t$. The dependent variable $y$ is a binary variable equal to 1 if there is at least one loan in household $i$ and 0 otherwise. Remit is a dummy variable equal to 1 if household $i$ receives remittances. The vector $X$ includes household head and general household characteristics. The household head characteristics are age, a binary variable for marital status and literacy, which is a proxy for education. At the household level, we control for the share of children, namely the share of people less than 14 years old in the household. We also control for the polygamy status of the household, which can influence the likelihood of securing a loan due to the supplementary expenses that this situation involves. The household characteristics further include ethnicity dummies for Wolof, Pular and Mande ethnic groups. Ethnicity can influence migration behavior and thus remittances and loan access. Wolof is the largest ethnic group in Senegal. Many people coming from the Pular ethnic group often have livestock holdings, which are an indicator of wealth. The Mande ethnic group includes Soninke, Mandingue and Diakhanke people, who have a long tradition of migration and important migrants' networks abroad. Since we do not have information about the household income and expenditure, we use the wealth of the household as a proxy for income. We measure wealth through durable assets such as ownership of a radio and mobile phone - which also captures access to information - as well as the number of plots owned. We also use binary variables to control for the dwelling situation, such as the availability of drinking water, access to electricity and whether the household lives in a concrete house. We control for a dummy equal to 1 if there are covariate or idiosyncratic shocks that can strongly influence both migration and loans. Indeed, a household can decide to respond to these shocks by deciding to let one of their member migrate or to take out a loan. The disturbance terms $\epsilon_{i t}$ are assumed to be normally distributed and clustered at the household level. This allows controlling for unobserved heterogeneity at the household level.

The plain OLS estimates show that the receipt of remittances is posi- 
tively and significantly $(\alpha=5 \%)$ related to the probability of having a loan in a household (Table 2, regression 1). This result is robust to the addition of socio-demographic controls for the household head and the household in general (Table 2, regression 2), proxies for wealth (Table 2, regression 3) and the occurrence of idiosyncratic and covariate shocks (Table 2, regression 4). However, the magnitude of the coefficient is reduced with the addition of control variables, declining from 0.057 to 0.049 from regression 1 to regression 4. This indicates that socio-demographic characteristics, the economic and environment context play a non-negligible role in securing loans. The receipt of remittances increases the likelihood of having a loan by 4.9 percentage points.

Other implications from the regressions are that the likelihood of having a loan in a household increases with the number of children. This demonstrates that expenses related to child care are a reason for getting into debt. Having access to electricity reduces the likelihood of having a loan in a household, while living in a concrete house and having a higher number of plots have the opposite effect. The ethnicity dummies Pular and Mande have a negative sign, although only the Pular ethnic group is significant. One possible explanation is a wealth effect, probably due to the fact that Pular have a professional activity that could make them richer. Pular are related to the Fulani ethnic group and often own assets such as livestock, which would thus reduce their need to borrow. Having a radio and mobile phone increases the likelihood of having a loan. This finding shows that access to information is positively correlated with the likelihood of having a loan in a household.

\subsection{Endogeneity of remittances and robustness checks}

The OLS regressions presented above do not consider the potential endogeneity of remittances. The first estimation concern is the non-random selection into migration. Households with and without remittances are probably not the same in terms of their unobservable characteristics and would react differently on the credit markets depending on the receipt of remittances. The second source of bias is the omitted variable bias related to some unobservable 
characteristics at the household level that can affect both remittances and loans. Finally, the third source of bias is the possible reverse causation between remittances and loans; namely, while the receipt of remittances can explain loans access, loans can also fund migration for one or several household members and thus explain the ensuing receipt of remittances. The survey further provides information about the source of loans, offering the possibility to differentiate between formal loans from official credit institutions and informal loans from relatives. This also allows testing the robustness of the results taking into account loans potentially granted by migrants. We rule out these sources of bias by using a fixed effects model and an instrumental variable approach.

To address the concerns related to the selection into the receipt of remittances and the omitted variable bias, we introduce household fixed effects in Equation (1), which gives the following specification:

$$
y_{i t}=\alpha+X_{i t}^{\prime} \beta+\text { Remit }_{i t}+\mu_{i}+\epsilon_{i t}
$$

In Equation (2), the household fixed effects denoted by $\mu_{i}$ allows controlling for the selection and household unobservable time invariant characteristics.

However, conditioning on household fixed effects does not completely deal with all endogeneity issues. To solve the possible reverse causality bias, we develop - in addition to the fixed effects model - an instrumental variable approach that relies on the location of villages and their distance in kilometers to the harbor of Dakar. The distance between villages and the harbor of Dakar is as an exogeneous measure of the cost of migration between 1900 and 1960, when the first Senegalese migrant networks were formed. Historical migration networks as well as the relation between the geographical location of early migration and transport infrastructure such as rail lines have been used in the literature to instrument current migration from Mexico to the U.S. (e.g. McKenzie and Rappoport, 2010; Dermirgüç-Kunt et al., 2011; Woddruff and Zenteno, 2007; Alcaraz et al., 2012). In the same vain, we take advantage of the fact that Senegal has a long migration tradition and 
the harbor of Dakar historically played a crucial role in both internal and international migrant flows. The harbor - opened in 1866 during the French colonial era - was one of the most important of West Africa. It was essential for the development of the city of Dakar, including its political and economic development (Morazé, 1936; Charpy, 1958, 2011). Consequently, it largely contributed to attract internal migrants who used to work in business and factories, as well as also in the harbor itself (Kuper, 1965). At the beginning of the twentieth-century until the end of the 1950s, it also played an important role in international migration from Senegal to other West African countries and France. For instance, the first wave of Senegalese migrants in France were demobilized "tirailleurs sénégalais" ${ }^{5}$, traders and sailors who mainly belonged to the Soninke and Toucouleur ethnic groups, as mentioned above. This initial migration developed over time and continues at present (Diop, 1993; Manchuelle, 1997; Robin et al., 2000; Azam and Gubert, 2005). The first-stage relationship relates the variable Distance - representing the village's distance to the harbor of Dakar - to the receipt of remittances:

$$
\text { Remit }_{i t}=a+X_{i t}^{\prime} b+c \text { Distance }_{j}+\mu_{i}+e_{i t}
$$

Finally, a remaining concern is that the instrument should meet the exclusion restriction. Put differently, the distance from the harbor of Dakar should only be correlated with loans through its effect on remittances. One possible source of bias is that loans are a driving force for investment, which is an important element for development. Therefore, the lack of access to credit markets can reduce a village's level of development, which in turn will positively affect the receipt of remittances through increased migration flows. We rule out this possible source of bias by controlling for the village's level of development through variables such as the evolution of poverty at the village level during the five years prior to the survey, as well as the existence of a school or cellular network in the village.

\footnotetext{
5 "Tirailleurs sénégalais" is a generic term labeling Sub-Saharan Africa soldiers who participated in the World War I and II as members of the French Colonial Army.
} 
Table 3, regression 1 presents the fixed effects model, whereby the positive and significant sign associated with the dummy receipt of remittances in Table 2 remains. However, the size of the coefficient is more important in terms of magnitude. After controlling for the household fixed effects model, receiving remittances increases the probability of having a loan by 11.8 percentage points. Table 3, regression 2 presents first-stage results from Equation (3). As expected, the variable distance - expressed in hundreds of kilometers is significant $(\alpha=5 \%)$ and negative. The second-stage estimation results are presented in Table 3, regression 3, whereby the significant and positive relationship between the receipt of remittances and the probability of having a loan remains robust after controlling for the potential endogeneity of remittances. It is useful to further test the validity of the instrument variable by controlling for the village's level of development through the evolution of poverty at the village level during the five years prior to the survey, as well as the existence of a school and cellular network in the village. The results obtained in Table 3, regression 4 and 5 are mostly unchanged compared to those obtained while not controlling for the village's level of development. The coefficients associated with the variable Remit are much higher while using the instrumental variable approach, mainly due to the size of standard errors after instrumenting. Therefore, in terms of magnitude, we prefer to be more conservative and retain the interpretation of the coefficient found in the fixed effect model (Table 3, regression 1).

\subsection{Heterogeneous effects}

The analysis carried out has considered all types of loans as a homogeneous group. However, it is worth exploring whether the complementarity between remittances and credit markets holds depending on whether the loan is taken for consumption or investment reasons, as well as whether it comes from formal or informal institutions. Indeed, the reasons for and origins of loans can vary, as shown in Table 4. A large proportion of the households took loans for consumption reasons (69.25\%). Households that use their loans for the purchase of food or the purchase of food during a hunger gap represent 
$44.18 \%$ of the sample of households with loans. Other categories included in the consumption reasons are the purchase of furniture or vehicles, family ceremonial expenditure, the repayment of another loan and other unclassified uses. Households with loans for investment represent $30.75 \%$ of the households with loans. The main uses of loans for investment are for professional reasons such as starting a professional activity (15.32\%) or buying equipment $(8.66 \%)$. Some loans are also taken for investment in human capital such as education and health expenditure or investment in housing. Out of 1,005 households with loans, $29.45 \%$ received loans provided by formal institutions, which includes commercial and mutualist banks, village funds and microfinance institutions. Households with loans from informal institutions represent $70.55 \%$ of the total number of households with loans. Informal institutions comprise employers, family relatives and relatives outside the family, "tontines", community stores and even other sources. Table 4 shows that formal loans are typically smaller in value than informal ones, as found in the literature (Fafchamps and Lund, 2003; Udry, 1994), although they are not as low as one may expect. Indeed, this may be due to the increasing presence of banking services such as microcredit.

In order to determine the extent to which the results are driven by the reasons for or origins of loans, we carry out a detailed analysis with the fixed effects and instrumental variable approach. In Table 5 , regression 1 , the dependent variable $y$ is a binary variable equal to 1 if there is at least one loan for consumption in the household and 0 if there is no loan in the household or if the loan is taken for investment reasons. Since food consumption is the main component of loans taken for consumption, as a dependent variable in Table 5, regression 2 we generate a dummy equal to 1 if there is at least one loan for the purchase of food or purchase of food during a hunger gap. The coefficients associated with the receipt of remittances in the case of loans for consumption and food are significantly different from zero and positive, thus suggesting complementarity. In Table 5, regression $3, y$ is a dummy equal to 1 if the loan is taken for investment reasons and 0 if there is no loan or if a loan is taken for consumption. We also generate a dummy variable if a loan is taken for professional reasons (Table 5, regression 4). The receipt 
of remittances does not affect the probability of having loans for investment and professional reasons. We further differentiate between loans from formal (Table 5, regression 5) and informal institutions (Table 5, regression 6). Upon first glance, the results suggest that receiving remittances increases the likelihood of having a loan from both formal and informal institutions in a household. However, the result is only statistically different from zero for loans provided by informal institutions (Table 5, regression 6). The analysis shows that the previous results hold when the instrumental variable approach is used (Table 6, Column 1 to 6). Overall, the findings show that the impact of remittances on credit markets is mainly driven by loans for consumption and more particularly the purchase of food - which includes the purchase of food during a hunger gap - as well as informal loans.

\section{Conclusion}

This paper studies the relationship between remittances and the likelihood of having a loan in a household. OLS estimates show a significant and positive impact of the receipt of remittances on credit markets. We introduce a household fixed effects and instrumental variable approach to test the robustness of the findings to the endogeneity of remittances, whereby the findings remain significant and positive. A detailed analysis shows that the results are driven by loans for consumption and food in particular, as well as loans from informal rather than formal institutions.

Overall, these results support the hypothesis that migrants increase the reliability of their family members and close relatives back home through their remittances, insuring them vis-à-vis lenders for their credit contracts. Accordingly, migrants play the role of collateral between borrowers and lenders in a credit contract. Consequently, these results reinforce the hypothesis of complementarity between remittances and credit markets.

These findings show that remittances are an important tool for consumption smoothing and they serve as an insurance because the left-behind have a leeway to delay their payments for food. At the same time, although Senegal is an important receiver of migrants' transfers - which significantly contribute 
to the country's economy - the left-behind do not fully depend on these remittance inflows but also on their "own" resources, above all for consumption and food. Consequently, this highlights that households will not be able to invest in both human capital and productive activity as long as their basic needs are not fulfilled.

\section{References}

Aggarwal, Reena, Demirgüç-Kunt, Asli, \& Pería, Maria Soledad Martínez. 2011. Do remittances promote financial development? Journal of Development Economics, 96(2), 255-264.

Alcaraz, Carlo, Chiquiar, Daniel, \& Salcedo, Alejandrina. 2012. Remittances, schooling, and child labor in Mexico. Journal of Development Economics, 97(1), 156 - 165.

Ambrosius, Christian, \& Cuecuecha, Alfredo. 2013. Are Remittances a Substitute for Credit? Carrying the Financial Burden of Health Shocks in National and Transnational Households. World Development, 46(C), $143-152$.

Azam, Jean-Paul, \& Gubert, Flore. 2005. Those in Kayes. The Impact of Remittances on Their Recipients in Africa. Revue économique, 56(6), $1331-1358$.

Brown, Richard P C, Carmignani, Fabrizio, \& Fayad, Ghada. 2011. Migrants' Remittances and financial Development: Macro- and Micro-level Evidence of a Perverse Relationship. OxCarre Working Papers 059. Oxford Centre for the Analysis of Resource Rich Economies, University of Oxford.

Charpy, J. 1958. La foundation de Dakar, 1845-1857-1869. Collection des documents inédits pour servir à l'histoire de l'Afrique occidentale française. Larose. 
Charpy, Jacques. 2011. Aux origines du port de Dakar. Outre-mers: revue d'histoire, 99(370-371), 301-317.

Conning, Jonathan, \& Udry, Christopher. 2007. Rural Financial Markets in Developing Countries. Handbook of Agricultural Economics, vol. 3. Elsevier. Chap. 56, pages 2857-2908.

Demirgüç-Kunt, Asli, Córdova, Ernesto López, Pería, María Soledad Martínez, \& Woodruff, Christopher. 2011. Remittances and banking sector breadth and depth: Evidence from Mexico. Journal of Development Economics, 95(2), 229-241.

Diop, Mamadou. 1993. L'immigration ouest-africaine en Europe. Etudes Internationales, 24(1), 111-124.

Fafchamps, Marcel, \& Lund, Susan. 2003. Risk-sharing networks in rural Philippines. Journal of Development Economics, 71(2), 261-287.

Gupta, Sanjeev, Pattillo, Catherine A., \& Wagh, Smita. 2009. Effect of Remittances on Poverty and Financial Development in Sub-Saharan Africa. World Development, 37(1), 104-115.

Kuper, Hilda. 1965. Urbanization and migration in West Africa. Univ of California Press.

Manchuelle, F. 1997. Willing migrants: Soninke labor diasporas, 1848-1960.

Mawhood, Rebecca, \& Gross, Robert. 2014. Institutional barriers to a 'perfect' policy: A case study of the Senegalese Rural Electrification Plan. Energy Policy, 73(0), $480-490$.

McKenzie, David, \& Rapoport, Hillel. 2010. Self-Selection Patterns in Mexico-U.S. Migration: The Role of Migration Networks. The Review of Economics and Statistics, 92(4), 811-821.

Mesnard, Alice. 2004. Temporary migration and capital market imperfections. Oxford Economic Papers, 56(2), 242-262. 
Morazé, Charles. 1936. Dakar. Annales de Géographie, 45(258), 607-631.

Ratha, D., Mohapatra, S., Ozden, C., Plaza, S., Shaw, W., \& Shimeles, A. 2011. Leveraging Migration for Africa: Remittances, Skills, and Investments. World Bank e-Library. World Bank Publications.

Richter, Susan M. 2008. The Insurance Role of Remittances on Household Credit Demand. 2008 Annual Meeting, July 27-29, 2008, Orlando, Florida 6261. American Agricultural Economics Association (New Name 2008: Agricultural and Applied Economics Association).

Robin, Nelly, \& Lalou, Richard. 2000. Facteurs d'attraction et de répulsion à l'origine des flux migratoires internationaux: rapport national Senegal.

Rosenzweig, Mark R. 1988. Risk, Implicit Contracts and the Family in Rural Areas of Low-income Countries. Economic Journal, 98(393), 1148-70.

Udry, Christopher. 1990. Credit Markets in Northern Nigeria: Credit as Insurance in a Rural Economy. World Bank Economic Review, 4(3), 251-69.

Udry, Christopher. 1994. Risk and Insurance in a Rural Credit Market: An Empirical Investigation in Northern Nigeria. Review of Economic Studies, 61(3), 495-526.

Woodruff, Christopher, \& Zenteno, Rene. 2007. Migration networks and microenterprises in Mexico. Journal of Development Economics, 82(2), $509-528$.

Yang, Dean, \& Choi, HwaJung. 2007. Are Remittances Insurance? Evidence from Rainfall Shocks in the Philippines. World Bank Economic Review, 21(2), 219-248. 
Table 1: Summary statistics by remittances status of the household

\begin{tabular}{|c|c|c|c|c|c|c|c|}
\hline \multirow[b]{2}{*}{ Variables } & \multicolumn{2}{|c|}{ Full sample } & \multicolumn{2}{|c|}{ Non recipients } & \multicolumn{2}{|c|}{ Recipients } & \multirow[t]{2}{*}{ Difference } \\
\hline & Mean & SD & Mean & S.D & Mean & S.D & \\
\hline \multicolumn{8}{|l|}{ Head characteristics } \\
\hline Age of household head & 53.64 & 14.61 & 52.8 & 14.52 & 55.52 & 14.65 & $-2.720^{* * *}$ \\
\hline Married houshold head & 0.93 & 0.25 & 0.94 & 0.25 & 0.93 & 0.25 & 0.004 \\
\hline Literate household head & 0.5 & 0.5 & 0.48 & 0.5 & 0.54 & 0.5 & $-0.065^{* * *}$ \\
\hline \multicolumn{8}{|l|}{ Household characteristics } \\
\hline Remit & 0.31 & & 0.46 & & & & \\
\hline Loan & 0.48 & 0.5 & 0.47 & 0.5 & 0.52 & 0.5 & $-0.057^{* *}$ \\
\hline Consumption loan & 0.33 & 0.47 & 0.33 & 0.47 & 0.35 & 0.48 & -0.029 \\
\hline Food loan & 0.25 & 0.43 & 0.24 & 0.43 & 0.27 & 0.44 & -0.025 \\
\hline Investment loan & 0.15 & 0.36 & 0.14 & 0.35 & 0.17 & 0.37 & $-0.028^{*}$ \\
\hline Professional loan & 0.12 & 0.32 & 0.11 & 0.31 & 0.13 & 0.34 & $-0.026^{*}$ \\
\hline Formal loan & 0.14 & 0.35 & 0.13 & 0.34 & 0.16 & 0.37 & -0.026 \\
\hline Informal loan & 0.34 & 0.47 & 0.33 & 0.47 & 0.36 & 0.48 & -0.031 \\
\hline Share of children & 0.43 & 0.17 & 0.43 & 0.17 & 0.42 & 0.16 & 0.012 \\
\hline Polygamous household & 0.5 & 0.5 & 0.48 & 0.5 & 0.56 & 0.5 & $-0.076^{* * *}$ \\
\hline Wolof ethnic group & 0.44 & 0.5 & 0.44 & 0.5 & 0.45 & 0.5 & -0.006 \\
\hline Pular ethnic group & 0.22 & 0.41 & 0.23 & 0.42 & 0.19 & 0.4 & $0.032^{*}$ \\
\hline Mande ethnic group & 0.06 & 0.23 & 0.05 & 0.22 & 0.07 & 0.26 & $-0.021^{* *}$ \\
\hline Radio & 0.77 & 0.42 & 0.76 & 0.43 & 0.79 & 0.41 & -0.029 \\
\hline Mobile phone & 0.77 & 0.42 & 0.77 & 0.42 & 0.76 & 0.43 & 0.012 \\
\hline Drinking water & 0.61 & 0.49 & 0.62 & 0.48 & 0.59 & 0.49 & 0.036 \\
\hline Access to electricity & 0.18 & 0.38 & 0.17 & 0.38 & 0.2 & 0.4 & $-0.034^{*}$ \\
\hline Concrete house & 0.41 & 0.49 & 0.39 & 0.49 & 0.45 & 0.5 & $-0.055^{* *}$ \\
\hline Number of plots & 2.57 & 1.15 & 2.51 & 1.15 & 2.69 & 1.15 & $-0.181^{* * *}$ \\
\hline Covariate shocks & 0.93 & 0 & 0.93 & 0.25 & 0.91 & 0.29 & $0.027^{* *}$ \\
\hline Idiosyncratic shock & 0.06 & 0.24 & 0.05 & 0.21 & 0.08 & 0.28 & $-0.036^{* * *}$ \\
\hline \multicolumn{8}{|l|}{ Village characteristics } \\
\hline Distance & 2.44 & 1.5 & 2.38 & 1.44 & 2.57 & 0 & $-0.187^{* * *}$ \\
\hline Stable poverty level & 0.18 & 0 & 0.18 & 0.38 & 0.18 & 0.38 & 0.001 \\
\hline Increase in poverty & 0.34 & 0.47 & 0.32 & 0.47 & 0.39 & 0.49 & $-0.067^{* * *}$ \\
\hline Existence of school & 0.84 & 0.36 & 0.83 & 0.38 & 0.87 & 0.34 & $-0.041^{* *}$ \\
\hline Cellular network & 0.79 & 0.41 & 0.81 & 0.39 & 0.74 & 0.44 & $0.068^{* * *}$ \\
\hline
\end{tabular}

Notes: Significance at $10 \%(*), 5 \%(* *)$ and $1 \%(* * *)$ level. The omitted category for the evolution of the poverty is decrease in poverty. 
Table 2: Remittances and Loan: OLS

\begin{tabular}{|c|c|c|c|c|}
\hline \multirow[b]{3}{*}{ Explanatory variables } & \multicolumn{4}{|c|}{ Dependent variable: Loan } \\
\hline & \multicolumn{4}{|c|}{ Ordinary Least Squares } \\
\hline & (1) & $(2)$ & $(3)$ & $(4)$ \\
\hline \multirow[t]{2}{*}{ Remit } & $0.057^{* *}$ & $0.054^{* *}$ & $0.052^{* *}$ & $0.049^{* *}$ \\
\hline & $(0.02)$ & $(0.02)$ & $(0.02)$ & $(0.02)$ \\
\hline \multirow[t]{2}{*}{ Age of household head } & & 0.000 & -0.000 & -0.000 \\
\hline & & $(0.00)$ & $(0.00)$ & $(0.00)$ \\
\hline \multirow[t]{2}{*}{ Married household head } & & 0.024 & -0.000 & -0.001 \\
\hline & & $(0.05)$ & $(0.04)$ & $(0.05)$ \\
\hline \multirow[t]{2}{*}{ Literate household head } & & 0.033 & 0.012 & 0.011 \\
\hline & & $(0.02)$ & $(0.02)$ & $(0.02)$ \\
\hline \multirow[t]{2}{*}{ Share of children } & & $0.162^{* *}$ & $0.165^{* *}$ & $0.167^{* *}$ \\
\hline & & $(0.07)$ & $(0.07)$ & $(0.07)$ \\
\hline \multirow[t]{2}{*}{ Polygamous household } & & 0.022 & 0.010 & 0.009 \\
\hline & & $(0.02)$ & $(0.02)$ & $(0.02)$ \\
\hline \multirow[t]{2}{*}{ Wolof ethnic group } & & 0.028 & 0.017 & 0.018 \\
\hline & & $(0.03)$ & $(0.03)$ & $(0.03)$ \\
\hline \multirow[t]{2}{*}{ Pular ethnic group } & & $-0.096^{* * *}$ & $-0.078^{* *}$ & $-0.077^{* *}$ \\
\hline & & $(0.03)$ & $(0.03)$ & $(0.03)$ \\
\hline \multirow{2}{*}{ Mande ethnic group } & & -0.078 & -0.075 & -0.085 \\
\hline & & $(0.05)$ & $(0.05)$ & $(0.05)$ \\
\hline \multirow[t]{2}{*}{ Radio } & & & $0.050^{*}$ & $0.050^{*}$ \\
\hline & & & $(0.03)$ & $(0.03)$ \\
\hline \multirow[t]{2}{*}{ Mobile } & & & $0.122^{* * *}$ & $0.122^{* * *}$ \\
\hline & & & $(0.03)$ & $(0.03)$ \\
\hline \multirow[t]{2}{*}{ Drinking water } & & & -0.023 & -0.025 \\
\hline & & & $(0.02)$ & $(0.02)$ \\
\hline \multirow[t]{2}{*}{ Access to electricity } & & & $-0.080 * * *$ & $-0.080 * * *$ \\
\hline & & & $(0.03)$ & $(0.03)$ \\
\hline \multirow[t]{2}{*}{ Concrete house } & & & $0.085^{* * *}$ & $0.086^{* * *}$ \\
\hline & & & $(0.02)$ & $(0.02)$ \\
\hline \multirow[t]{2}{*}{ Number of plots } & & & $0.016^{*}$ & $0.016^{*}$ \\
\hline & & & $(0.01)$ & $(0.01)$ \\
\hline \multirow[t]{2}{*}{ Covariate shocks } & & & & 0.020 \\
\hline & & & & $(0.08)$ \\
\hline \multirow[t]{2}{*}{ Idiosyncratic shocks } & & & & 0.090 \\
\hline & & & & $(0.09)$ \\
\hline Observations & 2,081 & 2,081 & 2,081 & 2,081 \\
\hline R-squared & 0.00 & 0.02 & 0.04 & 0.04 \\
\hline
\end{tabular}

Notes: Robust standard errors in parentheses. Significance at $10 \%(*), 5 \%(* *)$ and $1 \%(* * *)$ level. Standard errors are clustered at the household level. All estimates include a constant. 


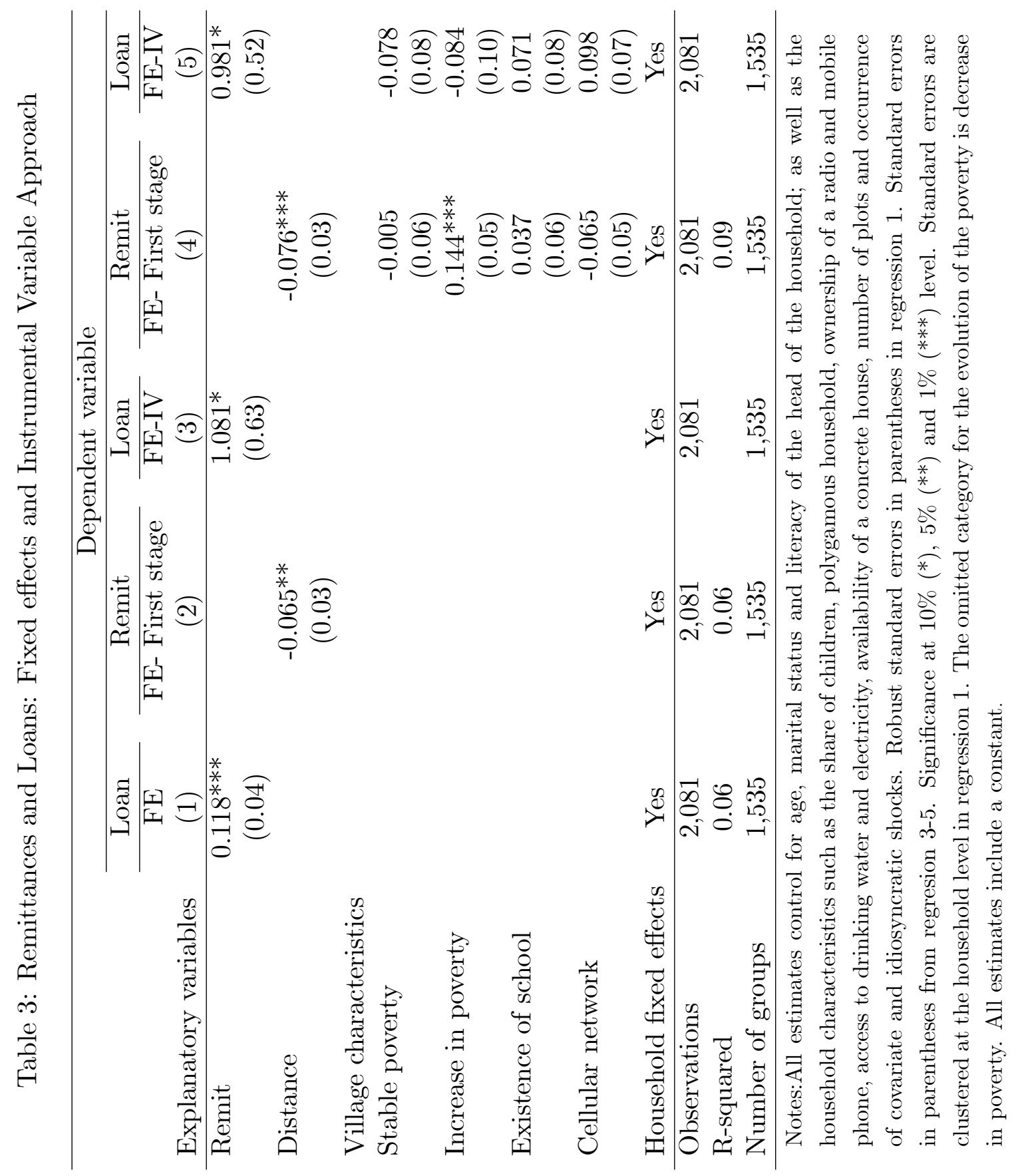


Table 4: Descriptives about the reasons for and origins of loans

\begin{tabular}{|c|c|c|}
\hline Reasons for loans & Number of household & Share of household(\%) \\
\hline \multicolumn{3}{|l|}{ Consumption reasons } \\
\hline Purchase of food & 444 & 44.18 \\
\hline Purchase of food during hunger gap & 76 & 7.56 \\
\hline Purchase of furnitures & 6 & 0.6 \\
\hline Purchase of vehicle & 3 & 0.3 \\
\hline Family celebration expenditures & 33 & 3.28 \\
\hline Payment of another loan & 14 & 1.39 \\
\hline Other uses & 120 & 11.94 \\
\hline \multicolumn{3}{|l|}{ Investment reasons } \\
\hline Purchase for professional activity & 87 & 8.66 \\
\hline Starting a professional activity & 154 & 15.32 \\
\hline Purchase of house & 20 & 1.99 \\
\hline Education expenditures & 7 & 0.7 \\
\hline Health expenditures & 41 & 4.08 \\
\hline Origins of loans & Number of household & Share of household (\%) \\
\hline \multicolumn{3}{|l|}{ Formal intitutions } \\
\hline Commercial Bank & 15 & 1.49 \\
\hline Mutualist bank & 133 & 13.23 \\
\hline Village funds & 58 & 5.77 \\
\hline Mircofinace institutions & 90 & 8.96 \\
\hline \multicolumn{3}{|l|}{ Informal institutions } \\
\hline Employer & 3 & 0.3 \\
\hline Family relative & 115 & 11.44 \\
\hline Relative outside the family & 238 & 23.68 \\
\hline Tontines & 26 & 2.59 \\
\hline Community store & 152 & 15.12 \\
\hline Others & 175 & 17.41 \\
\hline Number of households with loans & 1,005 & 100 \\
\hline
\end{tabular}




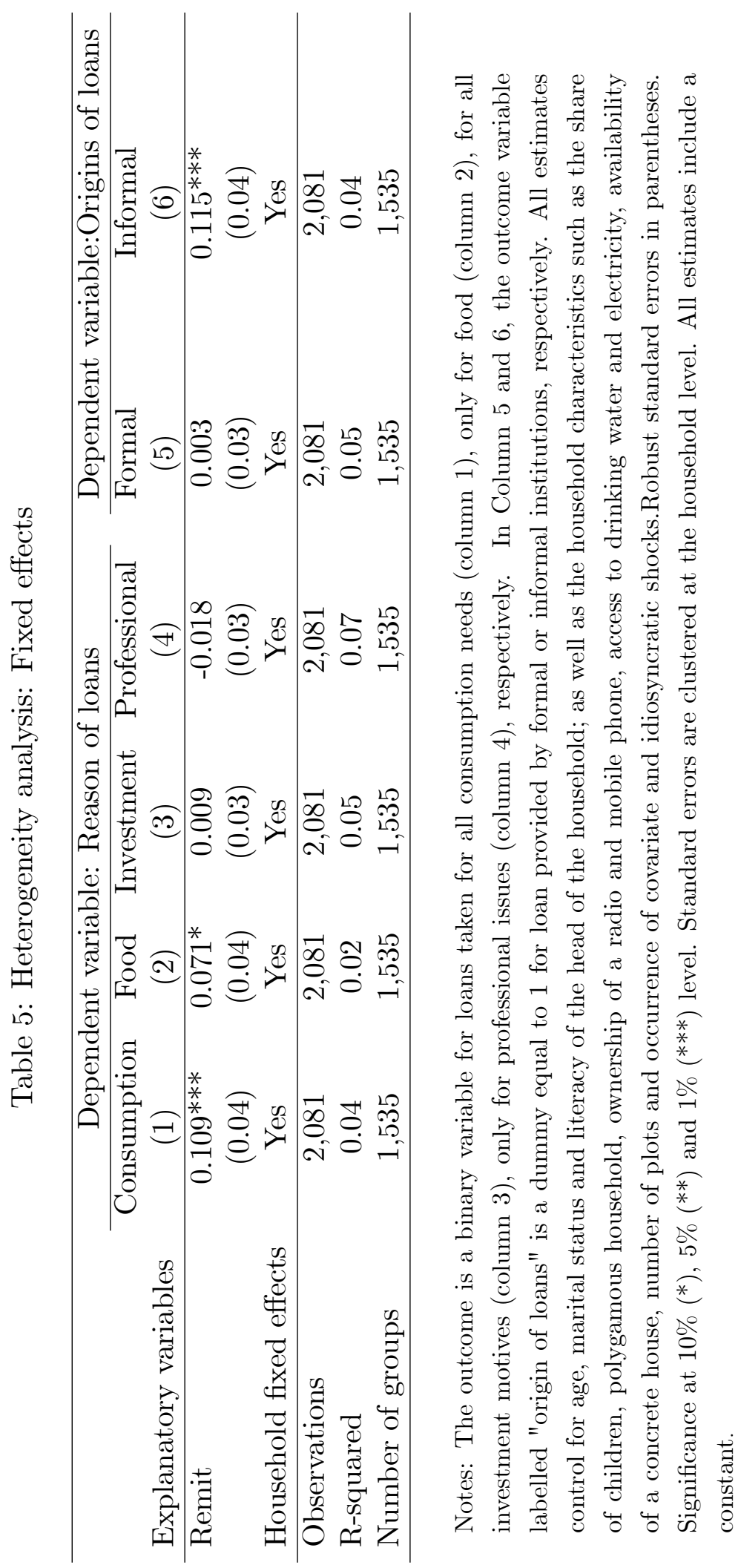




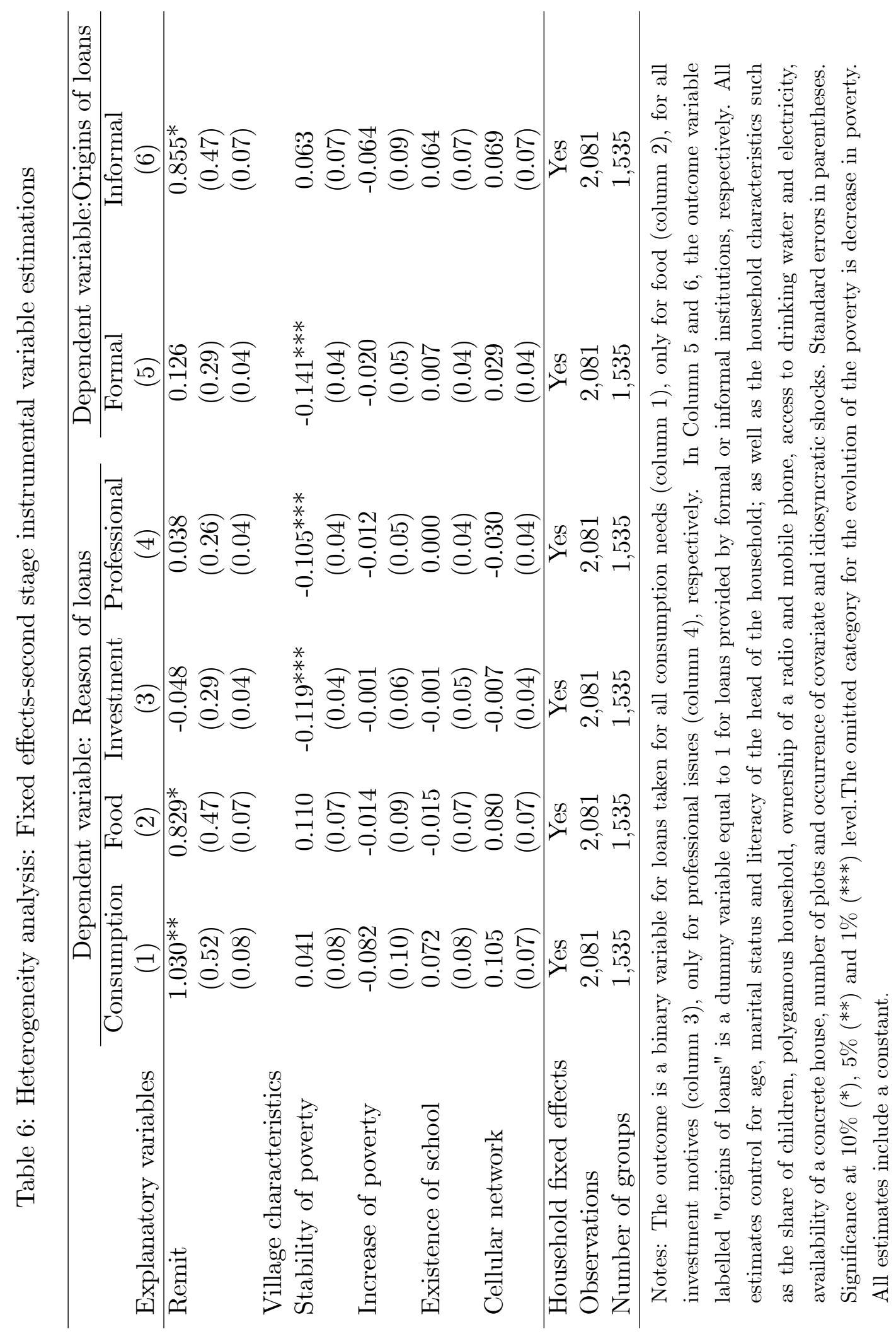


Table A1: Remittances and Loans: Fixed effects and Instrumental Variable Approach-full set of results

\begin{tabular}{|c|c|c|c|c|c|}
\hline \multirow[b]{4}{*}{ Explanatory variables } & \multicolumn{5}{|c|}{ Dependent variable } \\
\hline & Loan & Remit & Loan & Remit & Loan \\
\hline & $\mathrm{FE}$ & FE- First stage & FE-IV & FE- First stage & FE-IV \\
\hline & (1) & (2) & (3) & (4) & $(5)$ \\
\hline \multirow[t]{2}{*}{ Remit } & $0.118^{* * *}$ & & 1.081* & & $0.981^{*}$ \\
\hline & $(0.04)$ & & $(0.63)$ & & $(0.52)$ \\
\hline \multirow[t]{2}{*}{ Distance } & & $-0.065^{* *}$ & & $-0.076^{* * *}$ & \\
\hline & & $(0.03)$ & & $(0.03)$ & \\
\hline \multirow[t]{2}{*}{ Age of household head } & 0.002 & $0.004^{* * *}$ & -0.001 & $0.004^{* * *}$ & -0.002 \\
\hline & $(0.00)$ & $(0.00)$ & $(0.00)$ & $(0.00)$ & $(0.00)$ \\
\hline \multirow[t]{2}{*}{ Married household head } & -0.103 & $-0.154^{*}$ & 0.048 & $-0.140^{*}$ & 0.007 \\
\hline & $(0.08)$ & $(0.08)$ & $(0.15)$ & $(0.08)$ & $(0.13)$ \\
\hline \multirow[t]{2}{*}{ Literate household head } & 0.052 & $0.108^{* *}$ & -0.058 & $0.092^{* *}$ & -0.039 \\
\hline & $(0.04)$ & $(0.04)$ & $(0.09)$ & $(0.04)$ & $(0.08)$ \\
\hline \multirow[t]{2}{*}{ Share of children } & 0.118 & 0.023 & 0.129 & 0.031 & 0.136 \\
\hline & $(0.13)$ & $(0.13)$ & $(0.18)$ & $(0.13)$ & $(0.17)$ \\
\hline \multirow[t]{2}{*}{ Polygamous household } & 0.014 & -0.013 & 0.031 & -0.025 & 0.043 \\
\hline & $(0.04)$ & $(0.04)$ & $(0.06)$ & $(0.04)$ & $(0.06)$ \\
\hline \multirow{2}{*}{ Radio } & 0.078 & -0.004 & 0.089 & 0.004 & 0.086 \\
\hline & $(0.05)$ & $(0.05)$ & $(0.07)$ & $(0.05)$ & $(0.07)$ \\
\hline \multirow[t]{2}{*}{ Mobile phone } & $0.096^{*}$ & -0.050 & $0.130^{*}$ & -0.025 & 0.092 \\
\hline & $(0.05)$ & $(0.05)$ & $(0.07)$ & $(0.05)$ & $(0.07)$ \\
\hline \multirow[t]{2}{*}{ Driniking water } & -0.013 & 0.074 & -0.087 & 0.084 & -0.072 \\
\hline & $(0.05)$ & $(0.05)$ & $(0.09)$ & $(0.05)$ & $(0.09)$ \\
\hline \multirow[t]{2}{*}{ Access to electricity } & -0.087 & -0.013 & -0.082 & -0.028 & -0.079 \\
\hline & $(0.06)$ & $(0.06)$ & $(0.08)$ & $(0.06)$ & $(0.08)$ \\
\hline \multirow[t]{2}{*}{ Concrete house } & $0.084^{*}$ & 0.055 & 0.019 & 0.066 & 0.013 \\
\hline & $(0.05)$ & $(0.05)$ & $(0.08)$ & $(0.05)$ & $(0.08)$ \\
\hline
\end{tabular}


Table A1 (continued)

\begin{tabular}{|c|c|c|c|c|c|}
\hline \multirow[b]{4}{*}{ Explanatory variables } & \multicolumn{5}{|c|}{ Dependent variable } \\
\hline & Loan & Remit & Loan & Remit & Loan \\
\hline & $\mathrm{FE}$ & FE- First stage & FE-IV & FE- First stage & FE-IV \\
\hline & (1) & $(2)$ & $(3)$ & (4) & $(5)$ \\
\hline \multirow[t]{2}{*}{ Number of plots } & $0.041^{* *}$ & $0.037 * *$ & -0.000 & $0.033^{*}$ & 0.008 \\
\hline & $(0.02)$ & $(0.02)$ & $(0.04)$ & $(0.02)$ & $(0.03)$ \\
\hline \multirow[t]{2}{*}{ Covariate shocks } & -0.117 & 0.075 & -0.203 & 0.095 & -0.215 \\
\hline & $(0.11)$ & $(0.14)$ & $(0.21)$ & $(0.14)$ & $(0.20)$ \\
\hline \multirow[t]{2}{*}{ Idiosyncratic shocks } & -0.096 & 0.185 & -0.292 & 0.184 & -0.271 \\
\hline & $(0.14)$ & $(0.17)$ & $(0.27)$ & $(0.17)$ & $(0.25)$ \\
\hline \multirow[t]{2}{*}{ Stable poverty } & & & & -0.005 & -0.078 \\
\hline & & & & $(0.06)$ & $(0.08)$ \\
\hline \multirow[t]{2}{*}{ Increase in poverty } & & & & $0.144^{* * *}$ & -0.084 \\
\hline & & & & $(0.05)$ & $(0.10)$ \\
\hline \multirow[t]{2}{*}{ Existence of school } & & & & 0.037 & 0.071 \\
\hline & & & & $(0.06)$ & $(0.08)$ \\
\hline \multirow[t]{2}{*}{ Cellular network } & & & & -0.065 & 0.098 \\
\hline & & & & $(0.05)$ & $(0.07)$ \\
\hline Household fixed effects & Yes & Yes & Yes & Yes & Yes \\
\hline Observations & 2,081 & 2,081 & 2,081 & 2,081 & 2,081 \\
\hline R-squared & 0.06 & 0.06 & & 0.09 & \\
\hline Number of groups & 1,535 & 1,535 & 1,535 & 1,535 & 1,535 \\
\hline
\end{tabular}

Notes: Robust standard errors in parentheses in regression 1. Standard errors in parentheses in regressions 3-4. Significance at 10\% (*), 5\%(**) and 1\%(***) level. Standard errors are clustered at the household level in regression 1 . The omitted category for the evolution of the poverty is decrease in poverty. All estimates include a constant. 
Table A2: Heterogeneous analysis: Fixed effects -full set of results

\begin{tabular}{|c|c|c|c|c|c|c|}
\hline \multirow[b]{2}{*}{ Explanatory variables } & \multicolumn{4}{|c|}{ Dep.var.: Reason of loans } & \multicolumn{2}{|c|}{ Dep. var.:Origin of loans } \\
\hline & $\begin{array}{c}\text { Consumption } \\
\text { (1) }\end{array}$ & $\begin{array}{l}\text { Food } \\
(2)\end{array}$ & $\begin{array}{c}\text { Investment } \\
(3)\end{array}$ & $\begin{array}{c}\text { Professional } \\
\text { (4) }\end{array}$ & $\begin{array}{c}\text { Formal } \\
(5)\end{array}$ & $\begin{array}{c}\text { Informal } \\
(6)\end{array}$ \\
\hline Remit & $\begin{array}{c}0.109^{* * *} \\
(0.04)\end{array}$ & $\begin{array}{c}0.071^{*} \\
(0.04)\end{array}$ & $\begin{array}{l}0.009 \\
(0.03)\end{array}$ & $\begin{array}{l}-0.018 \\
(0.03)\end{array}$ & $\begin{array}{l}0.003 \\
(0.03)\end{array}$ & $\begin{array}{c}0.115^{* * *} \\
(0.04)\end{array}$ \\
\hline Age of household head & $\begin{array}{l}0.001 \\
(0.00)\end{array}$ & $\begin{array}{l}0.000 \\
(0.00)\end{array}$ & $\begin{array}{l}0.001 \\
(0.00)\end{array}$ & $\begin{array}{c}0.002^{* *} \\
(0.00)\end{array}$ & $\begin{array}{l}0.001 \\
(0.00)\end{array}$ & $\begin{array}{l}0.001 \\
(0.00)\end{array}$ \\
\hline Married household head & $\begin{array}{r}-0.065 \\
(0.07)\end{array}$ & $\begin{array}{l}0.003 \\
(0.07)\end{array}$ & $\begin{array}{r}-0.038 \\
(0.06)\end{array}$ & $\begin{array}{r}-0.036 \\
(0.05)\end{array}$ & $\begin{array}{c}-0.020 \\
(0.06)\end{array}$ & $\begin{array}{r}-0.083 \\
(0.07)\end{array}$ \\
\hline Literate household head & $\begin{array}{l}-0.032 \\
(0.04)\end{array}$ & $\begin{array}{r}-0.033 \\
(0.04)\end{array}$ & $\begin{array}{c}0.084^{* * *} \\
(0.03)\end{array}$ & $\begin{array}{l}0.051^{*} \\
(0.03)\end{array}$ & $\begin{array}{c}0.072^{* *} \\
(0.03)\end{array}$ & $\begin{array}{l}-0.020 \\
(0.04)\end{array}$ \\
\hline Share of children & $\begin{array}{l}0.133 \\
(0.13)\end{array}$ & $\begin{array}{l}0.079 \\
(0.13)\end{array}$ & $\begin{array}{l}-0.015 \\
(0.10)\end{array}$ & $\begin{array}{l}-0.070 \\
(0.09)\end{array}$ & $\begin{array}{r}-0.155^{*} \\
(0.09)\end{array}$ & $\begin{array}{c}0.272^{* *} \\
(0.13)\end{array}$ \\
\hline Polygamous household & $\begin{array}{l}-0.010 \\
(0.04)\end{array}$ & $\begin{array}{l}-0.057 \\
(0.04)\end{array}$ & $\begin{array}{l}0.024 \\
(0.03)\end{array}$ & $\begin{array}{l}0.032 \\
(0.03)\end{array}$ & $\begin{array}{l}0.007 \\
(0.03)\end{array}$ & $\begin{array}{l}0.007 \\
(0.04)\end{array}$ \\
\hline Radio & $\begin{array}{l}0.076 \\
(0.05)\end{array}$ & $\begin{array}{l}0.056 \\
(0.05)\end{array}$ & $\begin{array}{l}0.003 \\
(0.03)\end{array}$ & $\begin{array}{l}-0.004 \\
(0.03)\end{array}$ & $\begin{array}{l}0.020 \\
(0.03)\end{array}$ & $\begin{array}{l}0.058 \\
(0.05)\end{array}$ \\
\hline Mobile & $\begin{array}{l}0.047 \\
(0.05)\end{array}$ & $\begin{array}{l}0.011 \\
(0.05)\end{array}$ & $\begin{array}{l}0.049 \\
(0.04)\end{array}$ & $\begin{array}{l}0.033 \\
(0.03)\end{array}$ & $\begin{array}{l}-0.022 \\
(0.03)\end{array}$ & $\begin{array}{c}0.118^{* *} \\
(0.05)\end{array}$ \\
\hline Drinking water & $\begin{array}{l}0.003 \\
(0.05)\end{array}$ & $\begin{array}{l}0.016 \\
(0.05)\end{array}$ & $\begin{array}{r}-0.016 \\
(0.03)\end{array}$ & $\begin{array}{l}0.030 \\
(0.03)\end{array}$ & $\begin{array}{l}0.015 \\
(0.04)\end{array}$ & $\begin{array}{l}-0.028 \\
(0.05)\end{array}$ \\
\hline Access to electricity & $\begin{array}{c}-0.089^{*} \\
(0.05)\end{array}$ & $\begin{array}{l}-0.058 \\
(0.05)\end{array}$ & $\begin{array}{l}0.002 \\
(0.04)\end{array}$ & $\begin{array}{l}-0.002 \\
(0.04)\end{array}$ & $\begin{array}{l}-0.030 \\
(0.05)\end{array}$ & $\begin{array}{r}-0.057 \\
(0.06)\end{array}$ \\
\hline Concrete house & $\begin{array}{l}-0.008 \\
(0.05)\end{array}$ & $\begin{array}{r}-0.009 \\
(0.04)\end{array}$ & $\begin{array}{c}0.092^{* *} \\
(0.04)\end{array}$ & $\begin{array}{c}0.098^{* * *} \\
(0.03)\end{array}$ & $\begin{array}{c}0.093^{* *} \\
(0.04)\end{array}$ & $\begin{array}{l}-0.009 \\
(0.04)\end{array}$ \\
\hline
\end{tabular}


Table A2 (continued)

\begin{tabular}{|c|c|c|c|c|c|c|}
\hline \multirow[b]{2}{*}{ Explanatory variables } & \multicolumn{4}{|c|}{ Dep.var.: Reason of loans } & \multicolumn{2}{|c|}{ Dep. var.:Origin of loans } \\
\hline & $\begin{array}{c}\text { Consumption } \\
\text { (1) }\end{array}$ & $\begin{array}{c}\text { Food } \\
(2)\end{array}$ & $\begin{array}{c}\text { Investment } \\
(3)\end{array}$ & $\begin{array}{c}\text { Professional } \\
(4)\end{array}$ & $\begin{array}{c}\text { Formal } \\
(5)\end{array}$ & $\begin{array}{c}\text { Informal } \\
(6)\end{array}$ \\
\hline \multirow[t]{2}{*}{ Number of plots } & 0.020 & 0.021 & 0.022 & $0.030^{* *}$ & $0.026^{*}$ & 0.016 \\
\hline & $(0.02)$ & $(0.02)$ & $(0.01)$ & $(0.01)$ & $(0.01)$ & $(0.02)$ \\
\hline \multirow[t]{2}{*}{ Covariate shocks } & $-0.237^{* *}$ & -0.120 & 0.121 & 0.125 & 0.044 & -0.160 \\
\hline & $(0.12)$ & $(0.09)$ & $(0.08)$ & $(0.08)$ & $(0.08)$ & $(0.13)$ \\
\hline \multirow[t]{2}{*}{ Idiosyncratic shocks } & -0.153 & -0.019 & 0.056 & 0.068 & 0.025 & -0.121 \\
\hline & $(0.14)$ & $(0.12)$ & $(0.10)$ & $(0.10)$ & $(0.11)$ & $(0.15)$ \\
\hline Household fixed effects & Yes & Yes & Yes & Yes & Yes & Yes \\
\hline Observations & 2,081 & 2,081 & 2,081 & 2,081 & 2,081 & 2,081 \\
\hline R-squared & 0.04 & 0.02 & 0.05 & 0.07 & 0.05 & 0.04 \\
\hline Number of groups & 1,535 & 1,535 & 1,535 & 1,535 & 1,535 & 1,535 \\
\hline
\end{tabular}

Notes:The outcome is a binary variable for loans taken for all consumption needs (column 1), only for food (column 2), for all investment motives (column 3), only for professional issues (column 4), respectively. In Column 5 and 6 , the outcome variable labelled "origin of loans" is a dummy equal to 1 for loan provided by formal or informal institutions, respectively. Robust standard errors in parentheses. Significance at $10 \%(*), 5 \%(* *)$ and 1\% (***) level. Standard errors are clustered at the household level. The omitted category for the evolution of the poverty is decrease in poverty. All estimates include a constant. 
Table A3: Heterogeneous analysis: Fixed effects and Second stage instrumental variable estimates-full set of results

\begin{tabular}{|c|c|c|c|c|c|c|}
\hline \multirow[b]{2}{*}{ Explanatory variables } & \multicolumn{4}{|c|}{ Dep. var.: Reason of loans } & \multicolumn{2}{|c|}{ Dep. var.:Origins of loans } \\
\hline & $\begin{array}{c}\text { Consumption } \\
\text { (1) }\end{array}$ & $\begin{array}{l}\text { Food } \\
(2)\end{array}$ & $\begin{array}{c}\text { Investment } \\
(3)\end{array}$ & $\begin{array}{c}\text { Professional } \\
(4)\end{array}$ & $\begin{array}{c}\text { Formal } \\
(5)\end{array}$ & $\begin{array}{c}\text { Informal } \\
(6)\end{array}$ \\
\hline \multirow[t]{2}{*}{ Remit } & $1.030^{* *}$ & $0.829 *$ & -0.048 & 0.038 & 0.126 & $0.855^{*}$ \\
\hline & $(0.52)$ & $(0.47)$ & $(0.29)$ & $(0.26)$ & $(0.29)$ & $(0.47)$ \\
\hline \multirow[t]{2}{*}{ Age of household head } & -0.003 & -0.003 & 0.001 & 0.001 & 0.000 & -0.002 \\
\hline & $(0.00)$ & $(0.00)$ & $(0.00)$ & $(0.00)$ & $(0.00)$ & $(0.00)$ \\
\hline \multirow[t]{2}{*}{ Married household head } & 0.056 & 0.113 & -0.049 & -0.025 & -0.009 & 0.016 \\
\hline & $(0.13)$ & $(0.12)$ & $(0.08)$ & $(0.07)$ & $(0.07)$ & $(0.12)$ \\
\hline \multirow[t]{2}{*}{ Literate household head } & -0.124 & -0.111 & $0.085^{*}$ & 0.040 & 0.054 & -0.093 \\
\hline & $(0.08)$ & $(0.07)$ & $(0.04)$ & $(0.04)$ & $(0.04)$ & $(0.07)$ \\
\hline \multirow[t]{2}{*}{ Share of children } & 0.147 & 0.095 & -0.010 & -0.069 & -0.143 & $0.279^{*}$ \\
\hline & $(0.17)$ & $(0.15)$ & $(0.10)$ & $(0.09)$ & $(0.10)$ & $(0.16)$ \\
\hline \multirow[t]{2}{*}{ Polygamous household } & 0.017 & -0.040 & 0.026 & 0.034 & 0.016 & 0.026 \\
\hline & $(0.06)$ & $(0.05)$ & $(0.03)$ & $(0.03)$ & $(0.03)$ & $(0.05)$ \\
\hline \multirow[t]{2}{*}{ Radio } & 0.084 & 0.069 & 0.002 & -0.006 & 0.022 & 0.064 \\
\hline & $(0.07)$ & $(0.06)$ & $(0.04)$ & $(0.03)$ & $(0.04)$ & $(0.06)$ \\
\hline \multirow[t]{2}{*}{ Mobile } & 0.050 & 0.029 & 0.041 & 0.033 & -0.033 & $0.125^{* *}$ \\
\hline & $(0.07)$ & $(0.06)$ & $(0.04)$ & $(0.03)$ & $(0.04)$ & $(0.06)$ \\
\hline \multirow[t]{2}{*}{ Drinking water } & -0.062 & -0.044 & -0.010 & 0.026 & 0.008 & -0.080 \\
\hline & $(0.09)$ & $(0.08)$ & $(0.05)$ & $(0.04)$ & $(0.05)$ & $(0.08)$ \\
\hline \multirow[t]{2}{*}{ Access to electricity } & -0.075 & -0.048 & -0.004 & -0.005 & -0.035 & -0.043 \\
\hline & $(0.08)$ & $(0.07)$ & $(0.04)$ & $(0.04)$ & $(0.04)$ & $(0.07)$ \\
\hline \multirow[t]{2}{*}{ Concrete house } & -0.090 & -0.068 & $0.102^{* *}$ & $0.100 * * *$ & $0.088^{* *}$ & -0.076 \\
\hline & $(0.08)$ & $(0.07)$ & $(0.04)$ & $(0.04)$ & $(0.04)$ & $(0.07)$ \\
\hline
\end{tabular}


Table A3:(continued)

\begin{tabular}{|c|c|c|c|c|c|c|}
\hline \multirow[b]{2}{*}{ Explanatory variables } & \multicolumn{4}{|c|}{ Dep. var.: Reason of loans } & \multicolumn{2}{|c|}{ Dep. var.:Origins of loans } \\
\hline & $\begin{array}{c}\text { Consumption } \\
\text { (1) }\end{array}$ & $\begin{array}{c}\text { Food } \\
(2)\end{array}$ & $\begin{array}{c}\text { Investment } \\
(3)\end{array}$ & $\begin{array}{c}\text { Professional } \\
\text { (4) }\end{array}$ & $\begin{array}{c}\text { Formal } \\
(5)\end{array}$ & $\begin{array}{c}\text { Informal } \\
(6)\end{array}$ \\
\hline \multirow[t]{2}{*}{ Number of plots } & -0.018 & -0.014 & 0.026 & $0.030^{*}$ & 0.024 & -0.016 \\
\hline & $(0.03)$ & $(0.03)$ & $(0.02)$ & $(0.02)$ & $(0.02)$ & $(0.03)$ \\
\hline \multirow[t]{2}{*}{ Covariate shocks } & $-0.354^{*}$ & -0.230 & 0.139 & 0.142 & 0.036 & -0.250 \\
\hline & $(0.20)$ & $(0.18)$ & $(0.11)$ & $(0.10)$ & $(0.11)$ & $(0.18)$ \\
\hline \multirow[t]{2}{*}{ Idiosyncratic shocks } & -0.363 & -0.222 & 0.093 & 0.090 & 0.019 & -0.290 \\
\hline & $(0.25)$ & $(0.22)$ & $(0.14)$ & $(0.12)$ & $(0.14)$ & $(0.22)$ \\
\hline \multicolumn{7}{|l|}{ Village characteristics } \\
\hline \multirow[t]{2}{*}{ Stability of poverty } & 0.041 & 0.110 & $-0.119^{* * *}$ & $-0.105^{* * *}$ & $-0.141^{* * *}$ & 0.063 \\
\hline & $(0.08)$ & $(0.07)$ & $(0.04)$ & $(0.04)$ & $(0.04)$ & $(0.07)$ \\
\hline \multirow[t]{2}{*}{ Increase of poverty } & -0.082 & -0.014 & -0.001 & -0.012 & -0.020 & -0.064 \\
\hline & $(0.10)$ & $(0.09)$ & $(0.06)$ & $(0.05)$ & $(0.05)$ & $(0.09)$ \\
\hline \multirow[t]{2}{*}{ Existence of school } & 0.072 & -0.015 & -0.001 & 0.000 & 0.007 & 0.064 \\
\hline & $(0.08)$ & $(0.07)$ & $(0.05)$ & $(0.04)$ & $(0.04)$ & $(0.07)$ \\
\hline \multirow[t]{2}{*}{ Cellular network } & 0.105 & 0.080 & -0.007 & -0.030 & 0.029 & 0.069 \\
\hline & $(0.07)$ & $(0.07)$ & $(0.04)$ & $(0.04)$ & $(0.04)$ & $(0.07)$ \\
\hline Household fixed effects & Yes & Yes & Yes & Yes & Yes & Yes \\
\hline Observations & 2,081 & 2,081 & 2,081 & 2,081 & 2,081 & 2,081 \\
\hline Number of groups & 1,535 & 1,535 & 1,535 & 1,535 & 1,535 & 1,535 \\
\hline
\end{tabular}

Notes: The outcome is a binary variable for loans taken for all consumption needs (column 1), only for food (column 2), for all investment motives (column 3), only for professional issues (column 4), respectively. In Column 5 and 6, the outcome variable labelled "origin of loans" is a dummy equal to 1 for loan provided by formal or informal institutions, respectively. Standard errors in parentheses. Significance at $10 \%(*), 5 \%(* *)$ and $1 \%(* * *)$ level.The omitted category for the evolution of the poverty is decrease in poverty. All estimates include a constant. 